\title{
OBJECTIVES AND RESOURCES USES RANKING IN SOLIDARITY PURCHASING GROUPS: LITERATURE REVIEW AND DESIGN PRINCIPLES
}

\begin{abstract}
Michela ASCANI, CREA Council for Agricultural Research and Economics, Research Centre for Agricultural Policies and Bioeconomy, Address: via Po, 14 - 00198 Roma, Italy, michela.ascani@crea.gov.it (corresponding author)

Gaetano MARTINO, Institute/department of Agricultural, Food and Environmental Sciences, University of Perugia, Address: Borgo XX Giugno, 74 - 00121 Perugia, Italy, gaetano.martino@unipg.it.

The objective of the paper is investigating food networks (FNs), focusing on the emerging of recurring themes in literature and investigating how the networks relationships may influence the resources uses in farming activities. The research was carried out through access to Web of Science and Scopus databases in order to investigate the literature on FNs. The period considered is 20002016, using as selected key words food networks, food and practices, alternative food networks. Then we selected and classified the resulting articles and identified a set of themes addressed in literature.

The main outcome of this analysis is the identification of the following themes: a) common/shared FNs characteristics; b) trust creation and embeddedness facilitated by face to face relations; c) role of FNs in transformation of food systems towards social, environmental and health objectives; d) food citizenship/sovereignty-civil engagement; e) values inspiring FNs objectives, namely sustainability, fairness/social justice, health protection, ethical consumption/political action; f) governance of the consumers-producers relations.

We argue that identified themes are dimensions related to FNs objectives. More precisely we then conceptualize the identified characteristics as drivers of the ranking of resource uses in farming systems. Elaborating on this idea we derive principles for supporting the design of governance of these groups. The study concludes pointing out the complexity of food networks and their capability to influence the resources uses by setting up flexible but resilient governance structures.
\end{abstract}

Keywords: Civic engagement, food networks, governance design, ranking of resources uses values, trust creation

\section{INTRODUCTION}

The broad category of food networks (FNs) as systems linking producers and consumers on a local scale, and solidarity purchasing groups (SPGs) among them, is rapidly expanding and proliferating and is not anymore a marginal phenomenon in food markets in Europe. At the same time, there is a growing interest in the multiplicity of FNs both in several fields of research (agri-food, rural sociology, geography, etc.) and policy making (Whatmore et al., 2003; Bos, Owen, 2016). In the current EU rural development policy, specific support is foreseen for short supply chains, local markets and network approach in a broad sense ${ }^{1}$. In addition, in the current debate on the future of the EU CAP, attention is devoted to the theme of short food supply chains as able to foster behavioral change and health and to networks as tools for social capital and governance in rural areas.

European literature on FNs discusses the potential of these systems as engines of rural economic growth (Goodman, 2004) and relates interest in them to several motivations, among which environmental, ethical and health concerns associated with conventional food supply systems (Bos, Owen, 2016; Wald, Hill, 2016; Du Puis, Goodman, 2005; Sassatelli, 2015; Kirwan, 2004; Lombardi et. Al, 2015; Cembalo et al., 2015; Forssel, Lankoski, 2015; Schermer, 2014; Navin, 2015; Lavín et al., 2015) and quality (Dixon, Richards, 2016; Thorsøe, Kjeldsen, 2016), reaction to uncertainties created by globalization of the food system (Thorsøe, Kjeldsen, 2016) and civic engagement in food production (Dixon, Richards, 2016; Kirwan, 2004).

Local food networks are very frequently referred to as "alternative food networks", in order to underline their alterity with respect to the characteristics of the mainstream food system (Watts et al., 2005) and also to the related underlying values. In literature they are frequently attributed the role of contributing to transforming food systems into

\footnotetext{
${ }^{1}$ Regulation (EU) No 1305/2013 of the European Parliament and of the Council of 17 December 2013 on support for rural development by the European Agricultural Fund for Rural Development (EAFRD) and repealing Council Regulation (EC) No 1698/2005, art. 35 - Cooperation.
}

Copyright (C) 2017 The Authors. Published by Aleksandras Stulginskis University. This is an open-access article distributed under the terms of the Creative Commons Attribution License (CC-BY 4.0), which permits unrestricted use, distribution, and reproduction in any medium, provided the original author and source are credited. 
more inclusive for consumers and more socially, environmentally, economically sustainable (Blay-Palmer et al., 2016; Cleveland et al., 2015).

The objective of the paper is analyzing this kind of local food networks, focusing on the emerging of recurring themes and dimensions in literature and investigating how the networks relationships may influence the resources uses in farming activities. In particular, we argue that identified themes are dimensions related to FNs objectives. We then conceptualize the identified characteristics as drivers of the ranking of resource uses in farming systems. Elaborating on this idea we finally derive principles for supporting the design of governance of these groups.

\section{RESEARCH METHODS}

The research was carried out by investigating literature on food networks accessing Web of Science and Scopus databases. The period considered is 2000-2016; we made queries on selected databases using as key words food networks, food and practices, alternative food networks. We collected relevant articles, then we analyzed the resulting items and identified a set of recurring themes addressed in literature, despite authors' theoretical background and perspectives (agricultural economics, rural sociology, geography, etc.). The themes include common characteristics emerging from studies on FNs. One of the themes, governance of the consumers-producers characteristics, is also the instrument allowing the achievement of FNs objectives. Subsequently, we contrasted the results of the literature review on the basis of the organization studies (Grandori, 2010), the institutional analysis (Ostrom, 2005) and of the food chain governance studies (Ménard, 2017; Grandori, 2017).

\section{RESEARCH RESULTS}

\section{Literature review and identification of recurring themes}

The main outcome of the analysis carried out on literature on food networks is the identification of the following recurring themes: a) common/shared FNs characteristics; b) trust creation and embeddedness facilitated by face to face relations; c) role of FNs in transformation of food systems towards social, environmental and health objectives; d) food citizenship/sovereignty-civil engagement; e) values inspiring FNs objectives, namely sustainability, fairness/social justice, health protection, ethical consumption/political action; f) governance of the consumers-producers relations.

5 out of 6 themes (a-e) are related to FNs objectives, while governance is the instrument for pursuing the objectives, defining the ranking of uses of resources within the networks/groups.

To be noted the recurrence of cited authors within the different (a-e) themes, underlining a coherence in outcomes in literature dealing with FNs, also from different disciplinary perspectives.

Concerning the first (a) aspect, FNs share some key characteristics, notably: alterity with respect to mainstream food systems, being more endogenous, territorialized and ecological models with respect to the conventional agri-food systems (Dupuis, Goodman, 2005; Hendrickson, Heffernan, 2002; Kirwan, 2004; Watts, 2005; Thorsøe, Kieldsen, 2016; Navin, 2015); being local and being short supply chains allowing consumer/producer closer relationships and direct interaction (Thorsøe, Kieldsen, 2016; Dixon, Richards, 2016; Navin, 2015; Bos, Owen, 2016; Seyfang, 2006; Lombardi et al., 2015; Lamine, 2005). A related aspect to the abovementioned is the smaller farm size characterizing producers and the presence in FNs of direct food retail venues, as farmers markets (Thorsøe, Kieldsen, 2016; Navin, 2015).

Trust creation and embeddedness (b) are a common feature to FNs, facilitated by the same fact of being local and short supply chains, that is to say by direct interaction. High levels of personal and systemic trust, conceptualized as outcome of face to face social relations, characterize FNs more than formal contractual obligations, typical of conventional food systems. Trust is at the same time a typical feature emerging by FNs characteristics and a mechanism facilitating further cooperation in FNs (Thorsøe, Kieldsen, 2016; Navin, 2015). Social embeddedness, related to social connectivity, reciprocity, trust, underpins local FNs and mediates self-interest in place of a concern for the wider common good (Sage, 2003; Seyfang, 2006).

FNs are acknowledged in literature to have a role in transformation of food systems towards social, environmental and health objectives (c). Being different with respect to conventional, large scale, agro-food systems, they are likely to produce change in modes of connectivity between production and consumption of food, reconnecting food to the social, cultural and environmental context of its production (Kirwan, 2004) and thickening producer-consumer relationships (Bos, Owen, 2016). This characteristic is strictly related to the next (d), dealing with food sovereignty, since FNs as local food systems seem to have the possibility of favoring socially embedded and inclusive economies of place and food systems (Seyfang, 2006; Blay-Palmer et al., 2016), places of consumers sovereignty, where relational component and participation mechanisms in consumption are relevant and give origin to socially, environmentally, economical sustainable food systems (Cleveland et al, 2015; Blay-Palmer et al., 2016).

The fourth recurring theme in analyzed literature, food citizenship, food sovereignty and civil engagement (d) is related to the dimension of participation and of relational characteristics of FNs. Food sovereignty, focused on local level control over production, is relevant for a just and sustainable economy of food (Wald, Hill, 2016), where local communities and civil society individually and collectively participate in food systems. Political action as civic engagement is also reflected in ethical consumption as kind of political practice (Navin, 2015; Dixon, Richards, 2016; Milani Marin, Russo, 2015; Blay-Palmer et al., 2016; Clarke et al., 2007, Schermer, 2014). Thus in FNs as SPGs and short food supply chains in general, food becomes an instrument of community building and social cohesion, expression of a set of values inspiring the same FNs objectives. 
Analyzing literature with respect to values (e) underpinning FNs and related actors motivations for participation in them, the main emerging categories are sustainability, fairness/social justice, health protection, ethical consumption/political action. In FNs literature, all of the abovementioned categories characterize "alternative" food networks with respect to conventional food supply systems.

FNs are seen as fields of cooperative behavior, opportunities both for farmers and consumers to satisfy selforiented and other-oriented motives, including social, health and environmental concerns and also psychological oriented preferences (Lavín et al., 2015; Cembalo et al., 2015; Migliore et al., 2015). Thus, ethical, environmental and health concerns and commitment to dimensions of food production and consumption other than mere production are central in food networks for the actors involved, first of all farmers and consumers, but also retailers, rural communities and other stakeholders.

Interpersonal interaction, individual responsibility, mutual endeavor are relevant elements, making FNs more than places and spaces of simple commodity exchange (Kirwan, 2004). They incorporate values other than market and quantity, as sustainability, common goods, gift relations, civic engagement, quality and taste, support of local agriculture and farmers and thus creation of sustainable wealth. FNs are perceived as ethically and environmentally focused, promoting goals of economic development and environmental sustainability, social justice and promotion of labor rights (Thorsøe, Kjeldsen, 2016; Navin, 2015; DuPuis, Goodman, 2005; Dixon, Richards, 2016; Whatmore et al., 2003; Seyfang, 2006; Lavín et al., 2015, Kirwan, 2004; Forssel, Lankoski, 2014; Lombardi et al, 2015), food safety and public health (Whatmore et al., 2003; Kirwan, 2004) also through the production of public goods. They are also acknowledged as contributing to objectives of food security and pursuing quality in production, by the frequent adoption of organic or low chemical input farming methods. In conclusion, actors involved in FNs share a common set of values around food production and consumption, as commitment to locality, ethics, fairness in social relations, animal welfare, environmental and economic sustainability, quality, taste and food related lifestyles. Identified characteristics and values are drivers of the ranking of resource uses in farming systems. Elaborating on this idea we derive principles for supporting the design of governance of these groups.

\section{Resources uses ranking and SPGs governance}

The effectiveness of a group is conditioned by its organizational basis. One problem is then how the many dimensions of the group can be effectively accounted for in the organizational design. We want to point here that a contribution to the understanding of the group effectiveness can be drawn from a focus on the allocation of decision rights and on the resources ranking.

The group can be considered hybrid organization as defined by the economics of governance (Mènard, 2013), whose characteristic organizational dimensions are the degree of decentralization of the decision rights and the pooling of property rights on central assets (Ménard, 2013). In the case of an SPG, the allocation of the decision rights concerns with the members, the assembly of the members, the product manager, the board (if any) and the national level network of SPGs. In order to carry out its activities a SPG owns and manages several resources. The group is endowed with codified and tacit knowledge about the production and consumption technologies; the group itself is also engaged in knowledge creation. Furthermore, it establishes relationships with other public and private entities, including the national level SPGs network. These relationships allow the group to tackle further knowledge and also to develop its political capability (Hassanein, 2003; Wilkins, 2003; Renting et al., 2012). The group also manages small amount of financial resources gathered at member level. Sometimes local public authorities grant the resources to support logistic activities. The producers own both material and immaterial resources: land, equipment, financial capital, labor and knowledge. The resources use objective is intended as the goal to which a given resource productive use is aimed; the goal may regard the quantity and the quality - or both - of the product (Martino et al., 2016).

The first design principle then concerns with the allocation of the decision rights among the group members: the theory states that the decision rights should be allocated to the agent which is held more able to cope with uncertainty (Gibbons, 2005). In the case of SPGs the main uncertainty at stake concerns with the environmental and health values. The health values are especially concerned with the consumers who seems more able to identify events that may influence the health property of the food and combine them with the food safety skills of the farmers. The main reason is that a public discourse on health food is just increasing and framing the agents beliefs (Aoki, 2010), while the consumers seem already more directly involved in such a discourse.

The second design principle regards the decision rights decentralization in itself. Because of the presence of many agents that are individual, collective, local and national, the decentralization of the decision rights may be under question. The democratic participation is instead a feature the group seeks to have (Renting et al., 2012). Therefore the group organization should be designed making coherent the allocation of the decision rights to the agent more competent (first principle), with the necessity to allow for participation of all the members.

The third design principle regards the resources ranking. The ranking of the resources uses objectives is the guidance of the resources ranking and a critical step in the constitution of the organization (Grandori, 2010). The citizens interested in organizing a group have to identify the objectives they want to pursue in terms of food characteristics and the other group activities. In organizational terms, this means that the group has to rank the potential resources uses with respect to the objectives. The resource ranking is not the result of simple unique decision of the group, but it rather emerges as the outcome of the organizational practices. We refer to practices based on group members' positions in the action situation as aimed at constituting the economic spaces where it operates (Martino et al., 2016; Delormier et al., 2010; Fonte, 2013). The objective entails specific resources uses. For example, purchasing local food requires the group 
to invest resources in seeking local producers; providing safe food requires to select products of producers or also direct the production process with the farmers. Even though the nexus between the group objectives and the resources uses could not be unique - as many technologies may be available - the ranking of the group objectives necessarily entail the resources uses ranking. Therefore the organization has to be shaped in such a way to allow the agents to implement the ranking of resources uses as identified by the group practices (Martino et al., 2016).

Table 1. Hypothetical design principles for SPGs

\begin{tabular}{|c|c|c|c|}
\hline $\begin{array}{l}\text { Organization } \\
\text { setting goals }\end{array}$ & $\begin{array}{l}\text { Allocation of decision rights } \\
\text { to cope with uncertainty } \\
\text { (first principle) }\end{array}$ & $\begin{array}{l}\text { Seeking to decentralize } \\
\text { the decision rights } \\
\text { (second principle) }\end{array}$ & $\begin{array}{l}\text { Shaping the organization } \\
\text { according to resources uses } \\
\text { ranking }\end{array}$ \\
\hline To identify objectives & $\begin{array}{ll}- & \text { Environment protection } \\
\text { - } & \text { Health } \\
\text { - } & \text { Civic engagement } \\
\end{array}$ & $\begin{array}{l}\text { Promoting embeddedness } \\
\text { and trust }\end{array}$ & $\begin{array}{ll}\text { - } & \text { Environment protection } \\
\text { - } & \text { Health } \\
\text { - } & \text { Civil engagement } \\
\end{array}$ \\
\hline To allocate responsibilities & $\begin{array}{l}\text { Planning: consumers, } \\
\text { farmers } \\
\text { - } \quad \text { Productionmanagement: } \\
\text { farmers } \\
\text { - Transportation: } \\
\text { farmers/group } \\
\text { - Logistic: group } \\
\text { specialized members } \\
\end{array}$ & $\begin{array}{l}\text { - Planning: consumers, } \\
\text { farmers } \\
\text { - Production management: } \\
\text { farmers } \\
\text { - Transportation: } \\
\text { farmers/group } \\
\text { - Logistic: group specialized } \\
\text { members } \\
\end{array}$ & \\
\hline To specify hierarchy & & Decentralization & \\
\hline $\begin{array}{l}\text { To identify relationships } \\
\text { among members }\end{array}$ & $\begin{array}{l}\text { Connecting consumers and } \\
\text { producers }\end{array}$ & & \\
\hline
\end{tabular}

\section{CONCLUSIONS AND DISCUSSION}

The study concludes underlying the complexity of food networks and their capability to influence the resources uses by setting up flexible but resilient governance structures. Design principles may further enhance the group effectiveness by channeling values.

Among results of literature review the emergence of the need for progress in knowledge and research in the field of FNs (Tregear, 2011; Goodman, 2004; DuPuis, Goodman, 2005; Cleveland et al., 2015; Wald, Hill, 2016; Clarke et al., 2007; Watts et al., 2005). Future research may focus on investigating still existing uncertainties on their nature and development: in particular, research underlined the need to better clarify the effective existence of a paradigm shift in terms of FNs as new modes of food provision and their central role in rural development.

\section{REFERENCES}

1. Blay-Palmer, A., Sonnino, R., Custot, J., 2016. A food politics of the possible? Growing sustainable food systems through networks of knowledge. Agriculture and Human Values, Vol. 33, pp. 27-43. https://doi.org/10.1007/s10460-015-9592-0

2. Bos, E., Owen, L., 2016. Virtual reconnection: The online spaces of alternative food networks in England. Journal of Rural Studies, Vol. 45, pp. 1-14. https://doi.org/10.1016/j.jrurstud.2016.02.016

3. Bravo, G., De Moor, T. 2008. The commons in Europe: from past to future. International Journal of the Commons, Vol. 2, Iss. 2, pp. 155-161. https://doi.org/10.18352/ijc.98

4. Brunori, G., Rossi, A. 2000. Synergy and Coherence through Collective Action: Some Insights from Wine Routes in Tuscany. Sociologia Ruralis, Vol. 40, Iss. 4, pp. 402-423. https://doi.org/10.1111/1467-9523.00157

5. Brunori, G., Rossi, A., Guidi, F. 2012. On the New Social Relations around and beyond Food. Analysing Consumers' Role and Action in Gruppi di Acquisto Solidale (Solidarity Purchasing Groups). Sociologia Ruralis, Vol. 52, pp. 1-30. https://doi.org/10.1111/j.1467-9523.2011.00552.x

6. Cembalo, L., Lombardi, A., Pascucci, S., Dentoni, D., Migliore, G., Verneau, F., Schifani, G., 2015. "Rationally Local": Consumer Participation in Alternative Food Chains. Agribusiness, Vol. 31, Iss. 3, pp. 330-352. https://doi.org/10.1002/agr.21419

7. Clarke, N., Barnett, C., Cloke, P., Malpass, A., 2007. Globalising the consumer: Doing politics in an ethical register. Political Geography, Vol. 26, pp. 231-249. https://doi.org/10.1016/j.polgeo.2006.10.009

8. Cleveland, D.A., Carruth, A., Mazaroli, D.N., 2015. Operationalizing local food: goals, actions, and indicators for alternative food systems. Agriculture and Human Values, Vol. 32, pp. 281-297. https://doi.org/10.1007/s10460-014-9556-9

9. Commission on Social Determinants of Health. 2008. Closing the gap in a generation. Health equity through action on the social determinants of health, Geneva: World Health Organization

10. Dixon, J., Richards, C., 2016. On food security and alternative food networks: understanding and performing food security in the context of urban bias. Agriculture and Human Values, Vol. 33, pp. 191-202. https://doi.org/10.1007/s10460-015-9630-y

11. DuPuis, E.M., Goodman, D., 2005. Should we go "home" to eat?: toward a reflexive politics of localism. Journal of Rural Studies, Vol. 21, pp. 359-371. https://doi.org/10.1016/j.jrurstud.2005.05.011

12. Entman, R. M. 1993. Framing: Toward clarification of a fractured paradigm. Journal of Communication, Vol. 43, pp. 51-58. https://doi.org/10.1111/j.1460-2466.1993.tb01304.x 
13. Fonte, C. M. 2013. Food consumption as social practice: Solidarity Purchasing Groups in Rome, Italy. Journal of Rural Studies 32 : 230-239. https://doi.org/10.1016/j.jrurstud.2013.07.003

14. Forssel, S., Lankoski, L., 2015, The sustainability promise of alternative food networks: an examination through "alternative" characteristics". Agriculture and Human Values, Vol. 32, pp. 63-75. https://doi.org/10.1007/s10460-014-9516-4

15. Giddens, A. 1984. The constitution of society: an outline of the theory of structuration. Cambridge, Polity Press

16. Goodman, D., 2004. Rural Europe Redux? Reflections on Alternative Agro-Food Networks and Paradigm Change. Sociologia Ruralis, Vol. 44, Iss. 1, pp. 3-16. https://doi.org/10.1111/j.1467-9523.2004.00258.X

17. Grandori, A., Furnari, S. 2008. A chemistry of organization: Combinatory analysis and design. Organization Studies, Vol. 29, Iss. (2), pp. 315-341. https://doi.org/10.1177/0170840607088023

18. Gray, B., Purdy, J. M., Ansari, S. S. 2015. From interactions to institutions: Microprocesses of framing and mechanisms for the structuring of institutional fields. Academy of Management Review, Vol. 40, pp. 115-143. https://doi.org/10.5465/amr.2013.0299

19. Hassanein, N. 2003. Practicing food democracy: a pragmatic politics of transformation. Journal of Rural Studies, Vol. 19, Iss. 1, pp. 77-86. https://doi.org/10.1016/S0743-0167(02)00041-4

20. Hendrickson, M.K., Heffernan, D., 2002. Opening Spaces through Relocalization: Locating Potential Resistance in the Weaknesses of the Global Food System. Sociologia Ruralis, Vol. 42, Iss. 4, pp. 347-369 https://doi.org/10.1111/1467-9523.00221

21. Jones, A., Murphy, J.T. 2010. Theorizing practice in economic geography. Foundation, challenges and possibilities. Progress in Human Geography, Vol. 35, pp. 366-392. https://doi.org/10.1177/0309132510375585

22. Kirwan, J., 2004. Alternative Strategies in the UK Agro-Food System: Interrogating the Alterity of Farmers' Markets. Sociologia Ruralis, Vol. 44, Iss. 4, pp. 395-415 https://doi.org/10.1111/j.1467-9523.2004.00283.x

23. Lamine, C., 2005. Settling Shared Uncertainties: Local Partnerships Between Producers and Consumers. Sociologia Ruralis, Vol. 45, Iss. 4, pp. 324-345. https://doi.org/10.1111/j.1467-9523.2005.00308.x

24. Lavín, C., Espejo, A., Bravo, D., Morales, S., 2015. What makes people decide to pay more? Understanding cooperation in the context of an alternative food network. Asian Journal of Social Psychology, Vol. 18, pp. 236-245. https://doi.org/10.1111/ajsp.12093

25. Lombardi, A., Migliore, G., Verneau, F., Schifani, G., Cembalo, L.,2015. Are "good guys" more likely to participate in local agriculture? Food Quality and Preference, Vol. 45, pp. 156-165. https://doi.org/10.1016/j.foodqual.2015.06.005

26. Martino, G., Giacchè, G., Rossetti, E. (2016). Organizing the Co-Production of Health and Environmental Values in Food Production: The Constitutional Processes in the Relationships between Italian Solidarity Purchasing Groups and Farmers. Sustainability, Vol. 8, Iss. 4, pp. 316. https://doi.org/10.3390/su8040316

27. Mènard, C., (2013) Hybrid modes of organization in Gibbons R. and Roberst J. (eds.), Handbook of Organizational Economics, Princeton, 1066-1106, Princeton University Press

28. Migliore, G., Schifani, G., Romeo, P., Hashem, S., Cembalo, L., 2015. Are farmers in Alternative Food Networks Social Entrepreneurs? Evidence from a Behavioral Approach. Journal of Agricultural and Environmental Ethics, Vol. 28, pp. 885-902.

29. Milani Marin, L.E., Russo, V., 2015. Re-localizing "legal" food: a social psychology perspective on community resilience, individual empowerment and citizen adaptations in food consumption in Southern Italy. Agriculture and Human Values, Vol. 33, pp. 179-190. https://doi.org/10.1007/s10460-015-9628-5

30. Navin, M., 2015. Scaling-Up Alternative Food Networks. Journal of Social Philosophy, Vol. 46, Iss. 4, pp. $434-448$.

Sage, C., 2003. Social embeddedness and relations of regard: alternative "good food" networks in south-west Ireland. Journal of Rural Studies, Vol. 19, pp. 47-60.

31. Newdick, C. 2006. Citizenship, free movement and health care: cementing individual rights by corroding social solidarity. Common Market Law Review, Vol. 43, pp. 1645-1668.

32. Obach, B. K., and Tobin, K. 2014. Civic agriculture and community engagement. Agriculture and human values, Vol. 31, Iss. 2 , pp. 307-322. https://doi.org/10.1007/s10460-013-9477-z

33. Renting, H., Marsden, T.K., and Banks, J. 2003. Understanding alternative food networks: exploring the role of short food supply chains in rural development. Environmental and Planning, Vol. 35, Iss. 3, pp. 339-411. https://doi.org/10.1068/a3510

34. Renting, H., Schermer, M., A. Rossi, A. 2012. Building Food Democracy: Exploring Civic Food Networks and Newly Emerging Forms of Food Citizenship. International Journal of Sociology of Agriculture and Food, Vol. 19, pp. 287-307.

35. Sage, C., 2003. Social embeddedness and relations of regard: alternative "good food" networks in south-west Ireland. Journal of Rural Studies, Vol. 19, pp. 47-60. https://doi.org/10.1016/S0743-0167(02)00044-X

36. Sahakian M., Wilhite, H. 2014. Making practice theory practicable: Towards more sustainable forms of consumption. Journal of Consumer Culture, Vol. 14, Iss. 1, pp. 25-44. https://doi.org/10.1177/1469540513505607

37. Sassatelli, R., 2015. Consumer culture, sustainability and new vision of consumer sovereignty. Sociologia Ruralis, Vol. 55 , Iss. 4. https://doi.org/10.1111/soru.12081

38. Schermer, M., 2014. From "Food from Nowhere" to "Food from Here": changing producer-consumer relations in Austria. Agriculture and Human Values, Vol. 32, pp. 121-132. ttps://doi.org/10.1007/s10460-014-9529-Z

39. Seely Brown, J., Duguid, P. 2001. Knowledge and organization: A social-practice perspective. Organization Science, Vol. 12 , Iss. 2, pp. 198-213. https://doi.org/10.1287/orsc.12.2.198.10116

40. Seyfang, G., 2006. Ecological citizenship and sustainable consumption: Examining local organic food networks. Journal of Rural Studies, Vol. 22, pp. 383-395. https://doi.org/10.1016/j.jrurstud.2006.01.003

41. Thorsøe, M., Kjeldsen, C., 2016. The Constitution of Trust: Function, Configuration and Generation of Trust in Alternative Food Networks. Sociologia Ruralis, Vol. 56, Iss. 2. https://doi.org/10.1111/soru.12082 
42. Tregear, A., 2011. Progressing knowledge in alternative and local food networks: Critical reflections and research agenda. Journal of Rural Studies, Vol. 27, pp. 419-430. https://doi.org/10.1016/j.jrurstud.2011.06.003

43. Wald, N., Hill, D.P., 2016. "Rescaling" alternative food systems: from food security to food sovereignty. Agriculture and Human Values, Vol. 33, pp. 203-213. https://doi.org/10.1007/s10460-015-9623-X

44. Warde, A. 2014. After Taste: Culture, Consumption and Theory of Practice. Journal of Consumer Culture, Vol. 14, pp. $279-303$. https://doi.org/10.1177/1469540514547828

45. Watts, D.C.H., Ilbery, B., Maye, D., 2005. Making reconnections in agro-food geography: alternative systems of food provision. Progress in Human Geography, Vol. 29, Iss. 1, pp. 22-40. https://doi.org/10.1191/0309132505ph526oa

46. Whatmore, S., Stassart, P., Renting, H., 2003. Guest editorial: What's alternative about alternative food networks? Environment and Planning, Vol. 35, pp. 389-391. https://doi.org/10.1068/a3621

47. Wilkins, J. L. 2005. Eating right here: moving from consumer to food citizen. Agriculture and Human Values, Vol. 22, Iss. 3, pp. 269-273. https://doi.org/10.1007/s10460-005-6042-4 